\title{
単位木造フレームを用いた動的・静的実験による木造軸組の耐震性能評価 DYNAMIC AND STATIC TESTS OF WOODEN FRAMES FOR EVALUATION OF SEISMIC PERFORMANCE
}

\author{
山田真澄*，鈴木祥之**，後藤正美***，清 水秀丸**** \\ Masumi YAMADA, Yoshiyuki SUZUKI, Masami GOTOU \\ and Hidemaru SHIMIZU
}

\begin{abstract}
The objective of this paper is to evaluate the seismic performance of wooden structures. First, shaking table tests and static tests of wooden unit frames installing various seismic elements have been carried out. Mud-plastered walls and penetrating tie beams were included in the specimens by considering Japanese traditional structure. From the results of these tests, the dynamic characteristics of wooden frames in terms of damage processes, hysteretic characteristics and hysteretic energy dissipation are clarified. From the comparison of dynamic tests and static tests, it is found that the skeleton curves of two tests are almost similar. It is emphasized that wooden frames with mud-plastered wall have the large deformability.
\end{abstract}

Keywords: Wooden frame, Seismic performance, Mud-plastered wall, Dynamic experiment, Static experiment, Deformability 木造軸組、而震性能、土壁、動的実験、静的実験、変形性能

\section{1. 研究の背景と目的}

1995 年兵庫県南部地震による阪神・淡路大震災で木造建築物は甚 大な被害を受け、木造住宅の耐震性能の確保・向上は重要かつ緊急 課題となった。震災後、建築基隻法が改正され、仕様規定から性能 規定への移行がなされた。さらに、住宅の品質確保の促進等に関す る法律の制定により住宅等の性能表示制度が設けられた。このよう な背景のもとに、木造建物の構造設計においては耐震性能の評価・ 検証が重要となっている。木造建物の主要な構法である軸組構法は、 木組みの複雑さや多種多様な地域特有の構法があり、構造解析が難 しく適切に耐震性能を評価するには課題が多く、実大軸組を用いた 実験に依らざるを得ない面がある（例えば文献 1$) 。$

木造軸組の耐震性能を評価するために、従来、木造軸組構面の実 大試験体を用いた静的加力実験が多くなされているが（例えば文献 2)、地震時のような動的状態での評価がなされていないため、静的 と動的での復元力特性や破壊性状の比較など地震時に想定された性 能が発揮されるのか検証されていない。また、静的評価においても、 筫かいの斜材や構造合板等の面材など耐力的な評価が主であり、木 造建物の特質である大きな変形性能に対する評価がなされていない。 本研究では、軸組構法の木造建物の耐震性能評価法を確立するた めに、柱と土台、桁から構成される単位木造軸組に各種の耐震要素 を組み込んだ試験体を用いて、振動台加振実験（以下動的実験）と 静的加力実験（以下静的実験）を行った（文献 3、4）。これらの実験 から木造軸組の動力学的特性とともに大変形領域にいたるまでの静 的および動的耐震性能の違いを明らかにする。

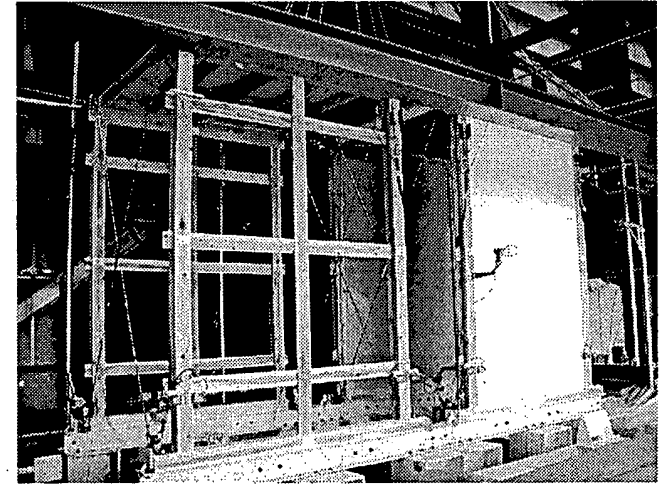

写真 1. 動的実験の様子

\section{2. 実験概要}

\section{1 試験体の概要}

試験体は、柱、桁と土台から構成される単純な単位軸組を製作し、 面内に様々な耐震要素を組み込んだ。試験体の軸組や柱頭、柱脚部の接 合部はすべての試験体で同じ仕様とし、柱の断面は105角で、接合部は 短ほぞ接合で山形プレート留めとした。

試験体の種類を表 1 に、試験体立面図を図 1 に示す。試験体の材種 は込み栓が樫材、桁が米松材、他はすべて杉材である。

軸組試験体は、すべての試験体の基本となる軸組だけの試験体で ある。

土壁を用いた試験体は、幅が 1 間の土壁試験体、幅が半間の土壁 半間試験体、屝が入ることを想定した土塗垂壁試験体、空を想定し

\footnotetext{
*カリフォルニア工科大学 大学院生・工修

** 京都大学防災研究所 教授. ‘博

*** 金沢工業大学建築学科 助教授・博士 (工学)

**** 京都大学防災研究所 研究員 - 博士(工学)
}

Graduate Student, California Institute of Technology, M. Eng.

Prof., Disaster Prevention Research Institute, Kyoto University, Dr. Eng.

Assoc. Prof., Department of Engineering Kanazawa Institute of Technology, Dr. Eng.

Researcher, Disaster Prevention Research Institute, Kyoto University, Dr. Eng. 


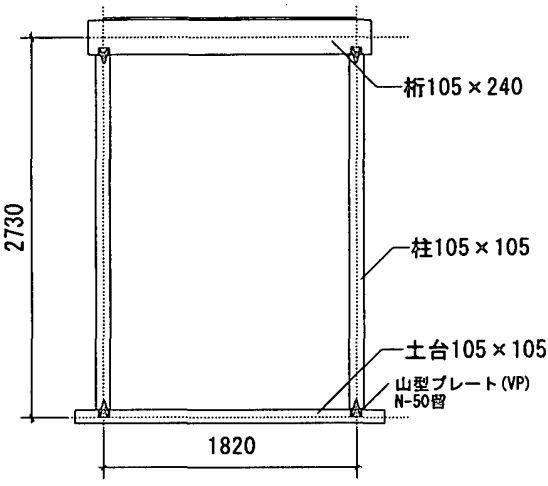

（a）軸組(短ほぞ 105 角)試験体

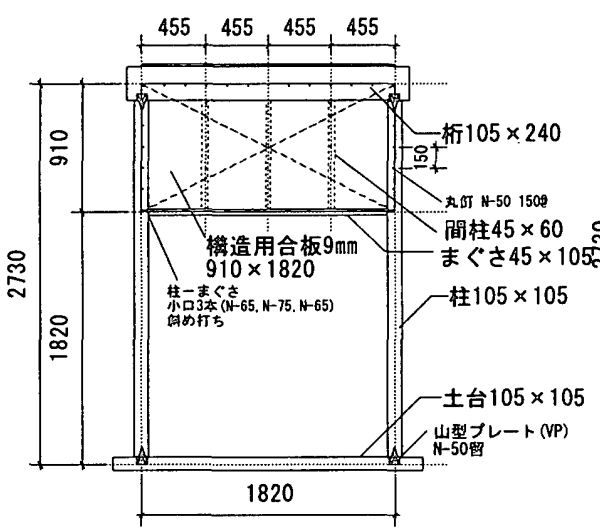

（d）合板垂壁試験体

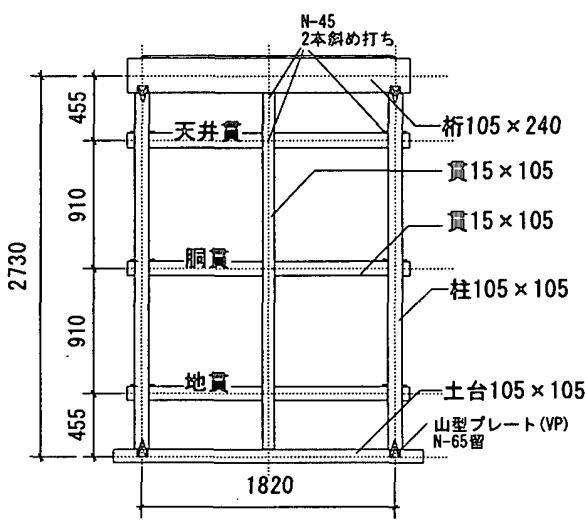

（g）貫試験体

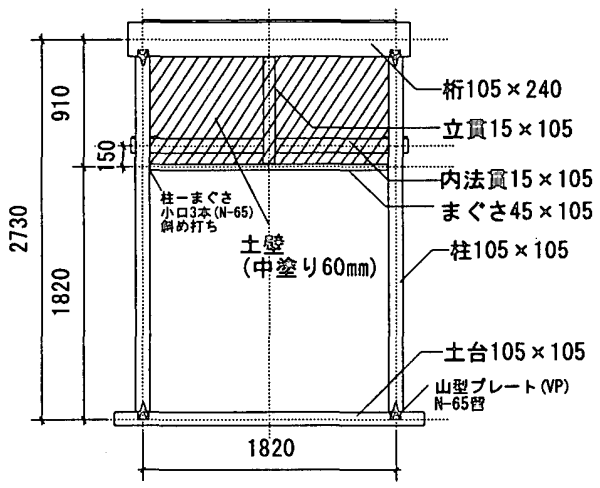

（b）土塗垂壁試験体

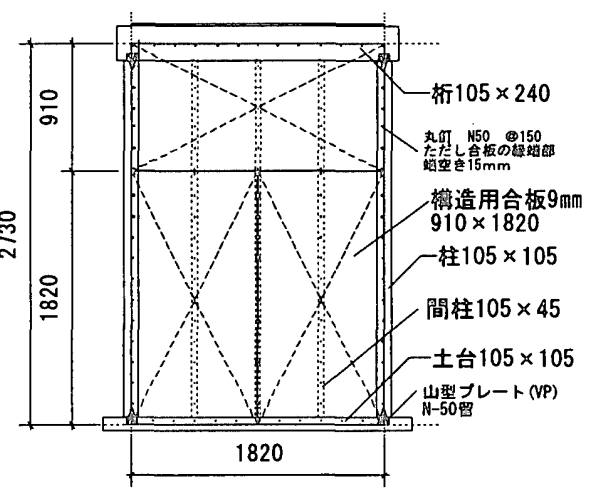

(e) 合板試験体

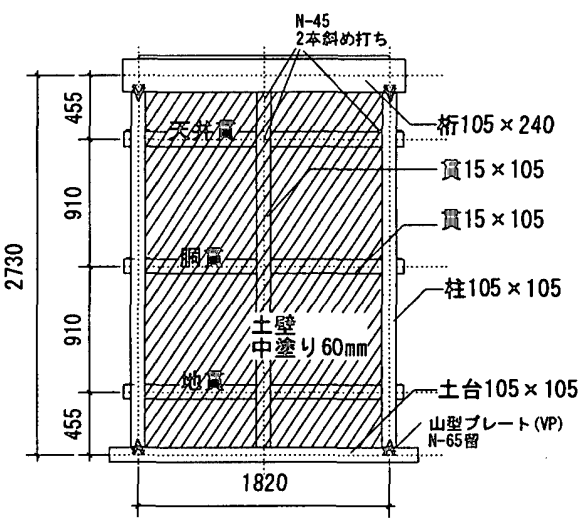

(h) 土壁試験体

図 1 試験体立面図

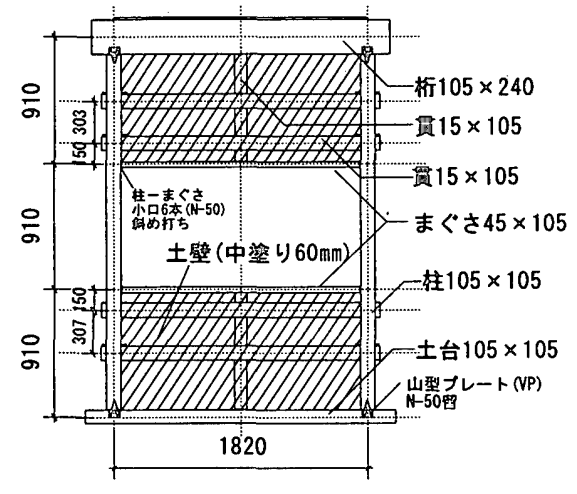

(c) 土塗垂壁腰壁試験体

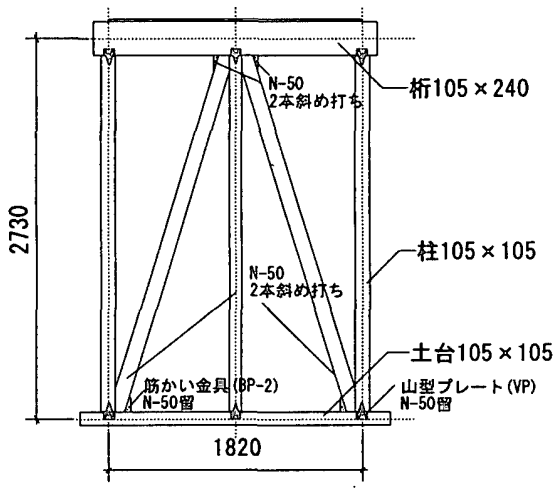

（f）筋汃試験体

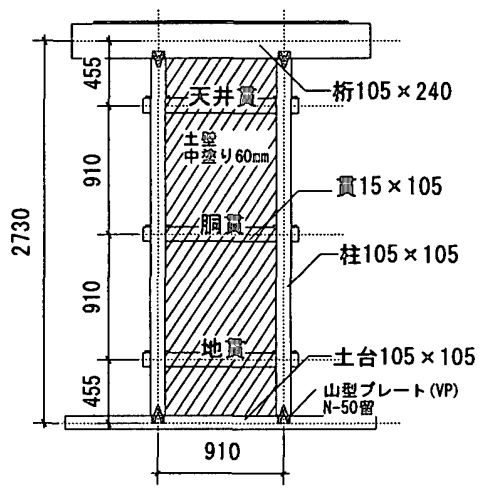

(i) 土壁半間試験体

表 1 試験体一覧

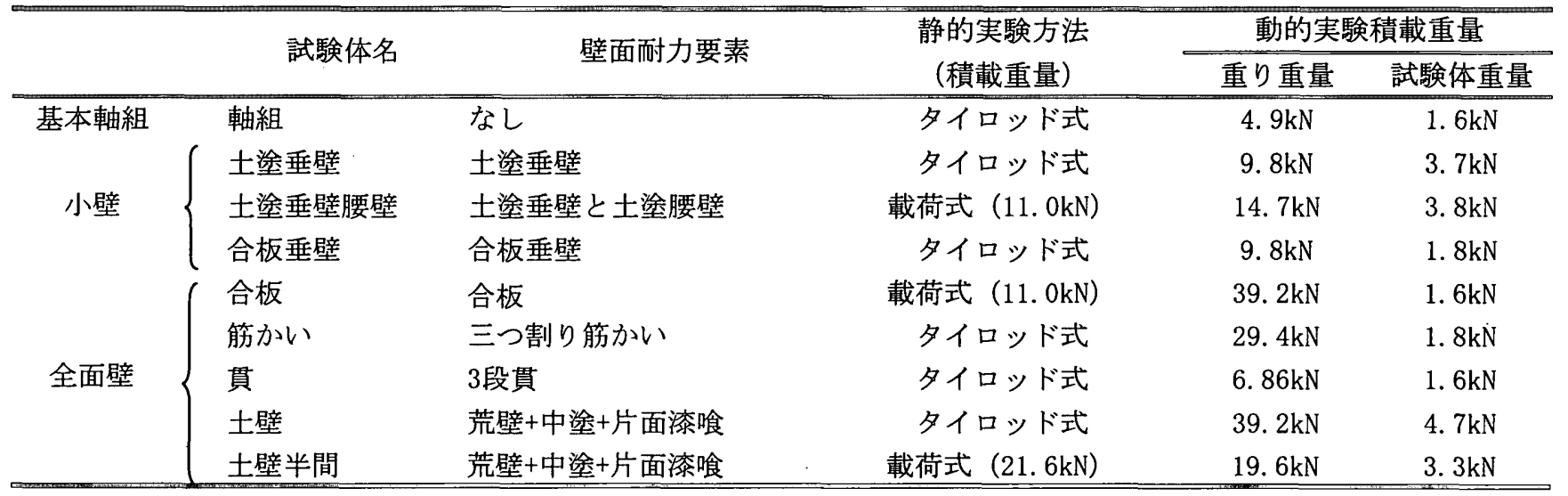




\section{た土塗垂壁腰壁試験体の4体を実験した。}

土壁を用いた試験体以外にも、在来構法に多用される筋かいや合 板などを実験し、現代的な構法に対する土壁の耐震性を検討した。

土壁は、すべての試験体で同一方法で製作した。木舞下地には割 竹を用い、間渡り竹を入れて、間に下地竹を縄で固定した。塗り厚 は、荒壁裏返し $36 \mathrm{~mm} 、$ 中塗り $11 \mathrm{~mm} \times 2$ (両面)、漆喰 $2 \mathrm{~mm}$ (片面) で 合計 $60 \mathrm{~mm}$ である。本論では、荒壁、中塗り、漆喰を合わせて壁土と 呼ぶことにする。壁土を塗り始めてから実験開始までの期間は、約 2ヶ月であった。

合板を用いた試験体は、455 mm間隔で細間柱を 3 本配置し、9 $\mathrm{mm}$ の 構造用合板を試験体外側のみに貼った。接合ファスナーには N-50 釘 を用い、打ち付け間隔は $150 \mathrm{~mm}$ である。

\section{2 計測方法}

動的実験では、試験体の桁中央に加速度計を設置し、試験体頂部 の加速度を計測している。この加速度の值に試験体上部の質量(表 1 に試験体重量として併記）を乗じ、1構面当りに換算した值を復元力 として用いている。静的実験では、アクチュエータと試験体の桁端 部の間にロードセルをはさんで、試験体の復元力を計測した。

層間変形角は、桁の端部中央と土台端部中央に設置した変位計よ り層間変位を算出し、それを試験体の高さ $2730 \mathrm{~mm}$ で除して層間変形 角とした。柱一横架材接合部には、柱左端と右端に変位計を設置し、 横架材までの相対変位を計測した。計測された柱左端と右端の変位 を変位計計測幅で除することによって、柱一横架材回転角を求めて いる。

柱脚及び柱頭には、柱端部から $200 \mathrm{~mm}$ の位置に歪ゲージを貼り付 け歪を計測した。さらに、小壁のある試験体ではまぐさの両端にも 歪ゲージを貼り、貫試験体と土壁試験体では 3 段貫のすべての材端 に歪ゲージを貼った。貼付位置は柱表面より $200 \mathrm{~mm}$ である。

\section{3 動的実験方法}

動的実験では、各種の耐震要素を組み込んだ同一の軸組 2 対を加 振方向に併置し、構造用合板 $24 \mathrm{~mm}$ の床を桁上部に固定して、一体の 立体型試験体とした。床上には重りを設置して、各試験体の固有周 期が 1.0 秒程度になるように調整した。各試験体の積載重量を表 1 に併記する。直交方向には倒壊及びねじれを防止するために、ステ ンレスブレースを配置した。

加振波には日本建築センター模擬波（BCJ-L2）を使用した。試験 体の振動特性、最大耐力や破壊性状を見るために、加速度レベルを $50 \mathrm{~cm} / \mathrm{s}^{2}$ (以下、Gal とする) 刻みで上げて、一体の試験体を繰り返 し加振した。試験体の破壊の進行に合わせて、スイープサイン波を $10 \sim 20 \mathrm{Gal}$ 程度のレベルで入力し、試験体の振動特性を把挃した。

\section{4 静的実験方法}

実験方法は、日本建築総合試験所「木造の耐力壁及び倍率性能試 験・評価業務方法書」に基づき、 1 種類の試験体につき 3 体ずつ試験 を行った。実験実施場所の設備に合わせて、土塗垂壁腰壁試験体、土 壁半間試験体、合板試験体は載荷式を、それ以外の試験体にはタイ ロッド式を用いた。

タイロッド式では、土台の両端をアンカーボルトで反カフレームに固 定し、試験体上部を振れ止めで固定して鉛直方向・面外方向へのはらみ を抑えている。試験体の析の一端にオイルジャッキを、他端に層間変形

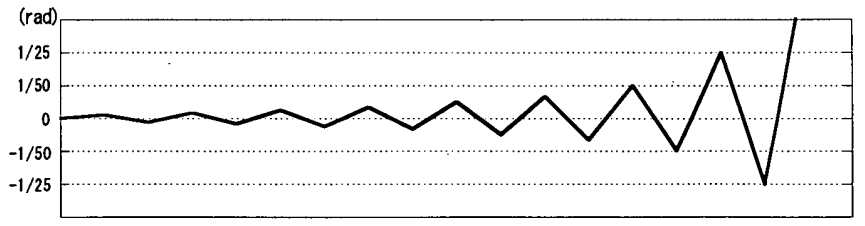

(a) タイロッド式

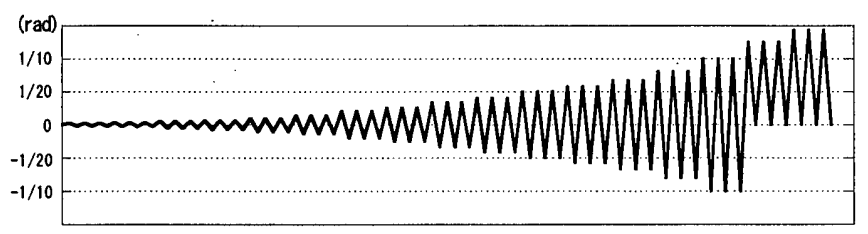

（b）載荷式

図 2 静的実験載荷スケジュール

角を計測するためのワイヤ変位計を取り付けた。

載荷式では、試験体の土台両端部を、ボルトを用いて反カフレー ムに固定した。加力時の試験体構面のねじれを防止するため、試験 体の析両端に加力治具を取り付け、反カフレームの間に挟み込んで 面外方向の変形を抑えた。試験体の柱の真上に載荷冶具を固定し、 そこから重りを市げた鋼棒を吊り下げ、鉛直方向に荷重がかかるよ うにした。試験体に載荷する重りは 3 体の試験体でそれぞれ変更し ているが、最も大きい変形角まで載荷できた試験体を採用した。載 荷した重りの重さは、土塗垂壁腰壁試験体と合板試験体が $11.0 \mathrm{kN}$ 、 土壁半間試験体が $21.6 \mathrm{kN}$ である。

載荷は変位制御とし、タイロッド式で行った実験では、水平方向 正負交番載荷を行った。載荷式で行った場合の加カスケジュールは、 繰り返し加力による損傷と復元力低下の影響を調べるために、1/ $10 \mathrm{rad}$ 変形時以下は正負交番 3 回繰り返し載荷とし、1/8rad 以降は アクチュエータのストロークの制限があるため正側のみ 3 回繰り返

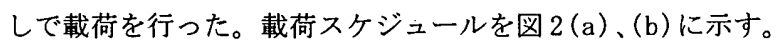

\section{3. 動的実験結果}

\section{1 破壊状況}

地震時に想定される破壊を確認するために、動的実験における各 試験体の大変形に至るまでの破壊状況と層間変形角との対応を図 3 に示す。また、図 4.(a)-(i) は各試験体の復元力特性である。履歷曲 線は、変形が大きく試験体の履歴特性をよく表していると思われる 加振を選んで描いた。太線実線は、各加振での最大忘答点を結んだ 包絡曲線である。図 4 (b) - (i) には比較のために, 点線で軸組試験体 の包絡曲線を描いている。

図 4 の復元力特性において急激に復元力が低下した原因となる破 壊を中心に、試験体の倒壊の危険性を生み出すような破壊、特徵的 な破壊を抽出して以下に記す。

土塗垂壁試験体と合板垂壁試験体は、軸組自体に破壊が生じた。 両試験体は約 $1 / 25 \mathrm{rad}$ 変形時に柱にまぐさの部分でひび割れが発生 した。この変形角を境として、復元力は急激に低下している。試験体解 体後に、柱が折損していたことが確認できた。軸組に垂壁を組み込むこ とは、軸組のみに比して耐力を向上させることができるが、柱の曲げ破 壊を生じないように垂壁のせん断耐力との兼和合いが重要となる。

筋かい試験体は、1/25rad変形時に右側の筋かいが1本折れた(写真2) 


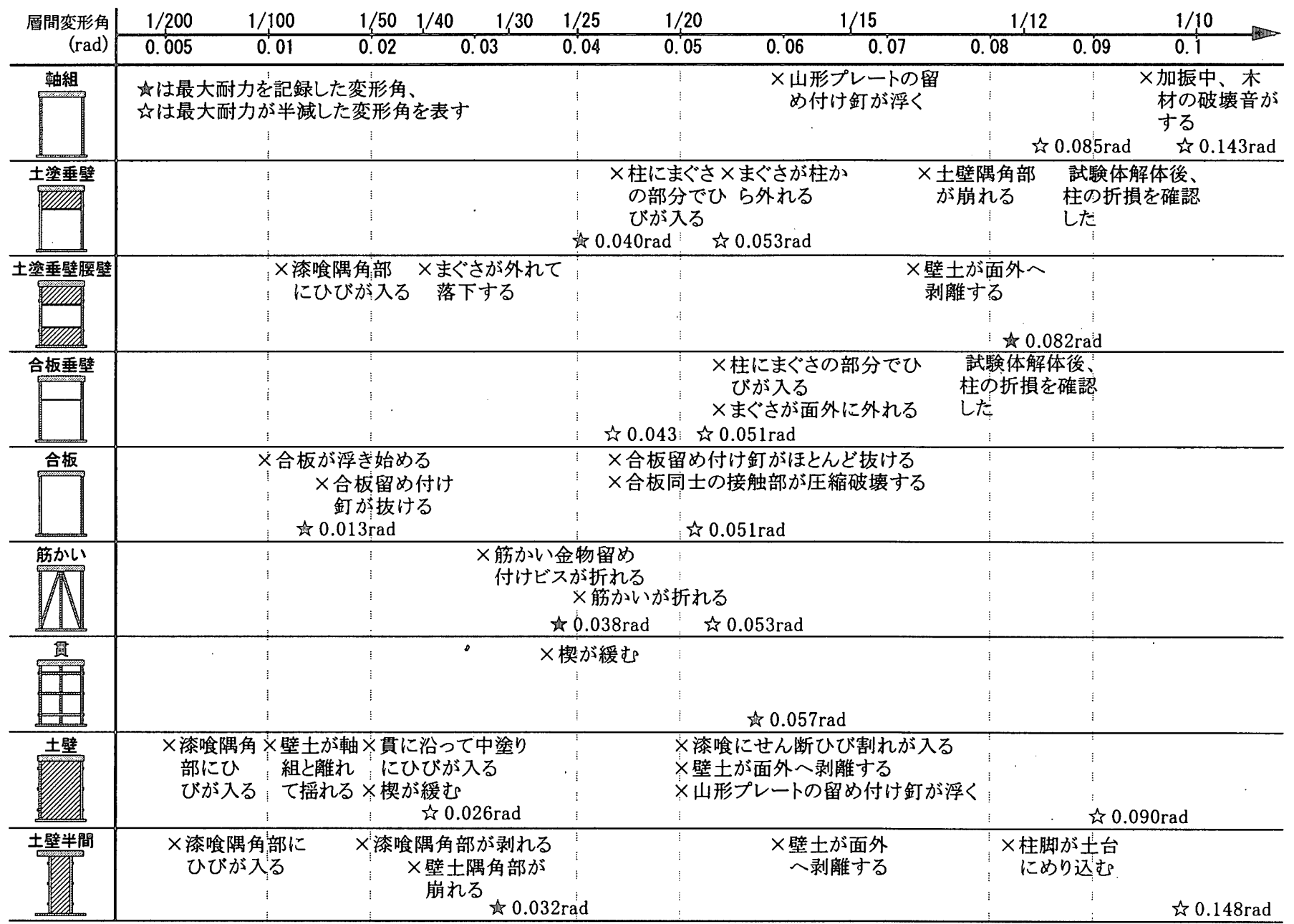

図 3 各試験体の動的実験の破壊状況

ため、その後の加振を中止した。

合板試験体は約 $1 / 70 \mathrm{rad}$ 変形時に合板の隅角部において合板留め 付け釘が浮き始めた。1/50 rad変形時には合板留め付け釘がほとんど抜 け出し(写真3)、合板同士の接触部では圧縮破壊が発生した(写真4)。合 板は軸組に固定されずわずかに接触するだけの状態となり、復元力は急 激に低下した。

土壁を用いた試験体の破壊状況には共通点が見られ、1/200 $\mathrm{rad}$ 程 度の微小変形時に漆喰隅角部にひびが入る(写真 5)。ただし復元力特 性に大きな影響はなく、変形が進むと共に復元力は上昇し続ける。 土壁隅角部が崩れ始めると(写真 6)、剛性は低下し始める。最大耐力 を経験するのは、土壁が面内すべてに塗られている全壁の試験体で、 1/50rad 前後である。壁土隅角部と軸組の接触が激しくなると、壁 土は剥がれ面外へ剥離し始める(写真 7)。静的実験において、1／ $10 \mathrm{rad}$ 以上変形した試験体では、壁土が竹小舞を残して一気に脱落 するという破壊が見られたが、動的実験ではほとんどの試験体で変 形角が 1/10rad までの加振を行っていないので、そのような破壊を 確認できなかった。

\section{2 変形性能}

構造物は、地震時にできるだけ変形しないことが望ましいが、た とえ大きく変形しても倒買を招くような破壊を起こさないことが重 要である。土壁などを有する木造軸組は、最大耐力を経験した後、復
元力特性が負勾配になってからも十分な耐力を保持し、耐震性を発 揮する場合があり、最大耐力のみで評価することができない。そこ で、変形が進んでも耐力が低下しない、あるいは低下の割合が緩や かで十分な耐力を有するという性質を変形性能としてとらえ、この 観点から評価を行った。

最大耐力更新後の挙動を調べるために、復元力が半減した時の変 形角を動的実験の結果より算出した。復元力特性の包絡曲線から、 復元力の最大点 (P max) と最大耐力を更新して復元力が半減した点 (0.5Pmax) を抽出し、図 5 に示す。包絡曲線には、正側と負側で異 なる傾向を示している試験体もあるが、できるだけ大変形時まで評 価できるよう、最大変形角が大きい側の包絡曲線を用いた。復元力 が半减するまで実験が行われなかった場合は、最大耐力を示した点 と、最大変形角を示した点を直線で結び、この直線上で復元力が 0.5Pmax 時の点を推定值として灰色の丸印で記した。筇かい試験体 では、動的実験では最大耐力を経験後に筋かいが破損したため復元 力低下時のデータが得られていないので、静的実験の包絡曲線を用 いてPmax、0.5Pmax を算出した。土塗垂壁腰壁試験体と貫試験体は、 静的実験、動的実験のどちらも大変形時に至るまで耐力が上昇し続 け、耐力低下時のデータが得られなかったため、P maxのみ記してい る。

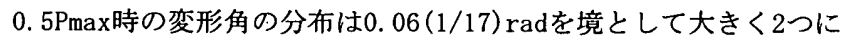




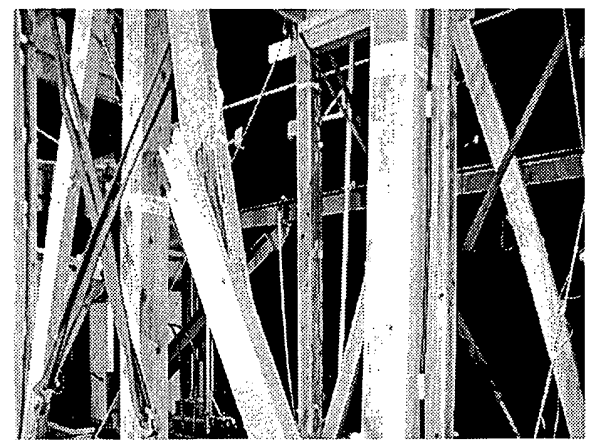

写真 2 筋かいの折損

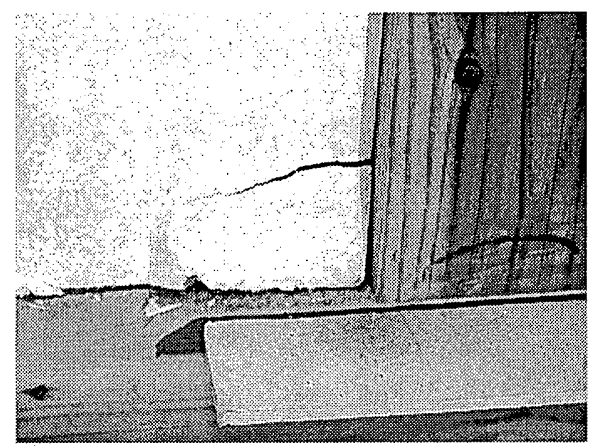

写真 5 漟喰隅角部のひび割れ

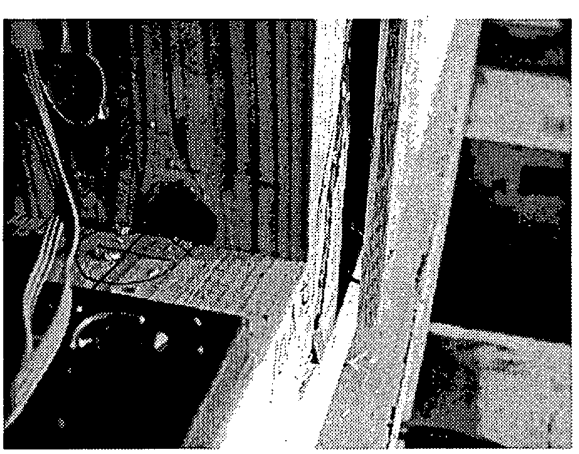

写真 3 合板留め付け釘の抜け

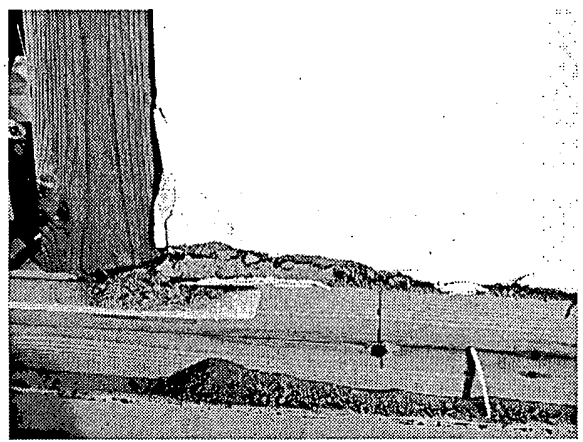

写真 6 土壁隅角部の崩れ

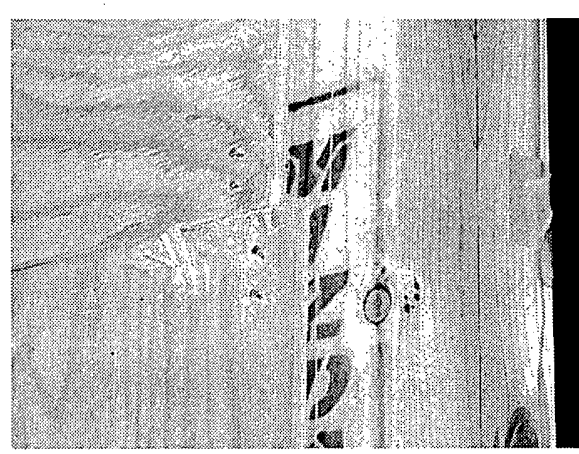

写真 4 合板の破壊

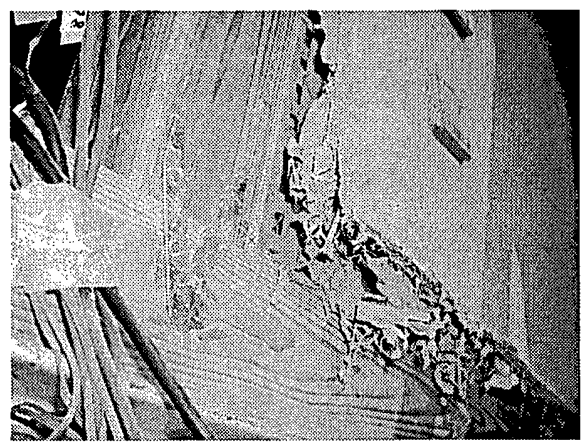

写真 7 土壁の面外への剥離
分類できる。垂壁のある試験体、筇かい試験体、合板試験体など、脆性 的な破壊が生じた試験体では、.06 (1/17) rad以下の小変形時に耐力が 半減した。土壁系、軸組系などの試験体は比較的変形が大きくなるまで 耐力が低下しなかった。

図 6 は代表的な $5 つ の$ 試験体について復元力をそれぞれの試験体の 最大耐力で割り、最大耐力を 1 として基淮化したものである。軸組 や貫試験体では、最大耐力に達した変形角が0.06rad以上であり、大変 形に至るまで復元力が上昇し続けるのに対し、土壁、筋かい、合板など の試験体では比較的小变形時に最大耐力を経験し、復元力が低下する。 ただし、合板試験体と土壁試験体を比較すると、合板試験体では最大耐 力に達した後、急激に耐力が低下しており、脆性的な破壊が発生し、変 形が進んでいる。一方、土壁試験体は最大耐力に達した後も徐々に低下 しており、土壁は漸次破壊しながらも抵抗力を保っていることが分かる。 筋かい試験体については筇かい破断後のデータが得られていないが、既 往の研究で笳かい破断後は耐力が急激に低下寸ることが確認されており (文献5)、図7(b)に示した静的実験の包絡曲線も同じ特徵を示している ことから、筋かいの変形性能は低いと思われる。

土壁などを有する伝統的な木造建物については、地震時に1/10 radを 超える大変形を起こしても、倒壊を免れた例が報告されている(文献6)。 これは、貫や土壁試験体において、変形が進んでも耐力が急激に低下し ないという実験結果に一致する。一方、筋かいや合板など、在来構法で 多用される耐震要素は、高い剛性あるいは耐力で地震力に抵抗するため、 変形性能という点では評価は低くなることが分かった。

\section{3 壁倍率}

建築基準法施行令第 46 条第 4 項表 1 の（八）に基づき、日本住宅・ 木造技術センターで開発された性能評価法を適用して、壁倍率を計 算した。壁倍率の算出には、(1)降伏耐力 (Py)、(2)真のせん断変形角
$1 / 150 \mathrm{rad}$ 時の耐力 (P150)、(3)最大荷重に $2 / 3$ を乗じたもの $(2 /$ $3 \mathrm{Pmax})$ 、(4)終局耐力に $(0.2 /$ 構造特性係数)を乗じたもの $(0.2 \mathrm{Pu} /$ Ds)のうち、最小值をせん断耐力として用いている。表 2 に動的実験 の結果から算出した耐力を示す。表中において太字は壁倍率を算出 する基準となった耐力を表す。壁倍率は、3体の試験体の平均值にば らつき係数を乗じて評価することになっているが、動的実験の試験 体数は 1 体のみなので、ばらつき係数は乗じていない。

表 2 において、静的実験の結果から算出した壁倍率を併せて示す。 動的実験結果から算出した壁倍率と比較すると、両者は比較的よく 一致している。一部の試験体で静的実験の壁倍率が動的実験よりも 小さいのは、ばらつき係数の影響だと考えられる。

現行の壁倍率と実験結果との比較では、合板試験体の実験結果か ら算出した壁倍率が静的・動的ともに小さい值となっている。合板 試験体では、壁倍率が終局耐力で決定されているように、最大耐力 更新後の急激な耐力低下がこのような低い評価につながったと考え られる。また、土壁試験体では、実験結果から算出した壁倍率が現 行の壁倍率よりも大きな值となっている。土壁の壁倍率については、 過去の実験からも評価が低いという結果が出ており（例えば文献 2、 8、9)、壁倍率の見直しがなされている。今後、土壁の材料や施工方 法の多様性、耐久劣化も考慮して、士壁の耐震性能を検証する必要 がある。

大変形時の耐震性能を評価するためには、耐力低下時の復元力ま で考虑しなければならないが、表中において合板試験体を除くすべ ての壁倍率は $1 / 150 \mathrm{rad}$ 変形時の耐力あるいは降伏耐力で決まってい る。これは、現行の壁倍率計算法では、最大耐力に至るまでの耐力 で壁倍率が決定されていることを表す。合板試験体のみは、終局耐 力で決まっているが、終局耐力の算出には 0.8Pmax 荷重低減域の包 


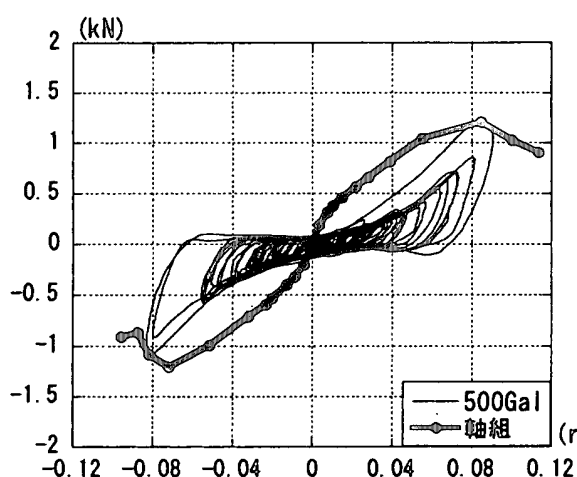

（a）軸組試験体

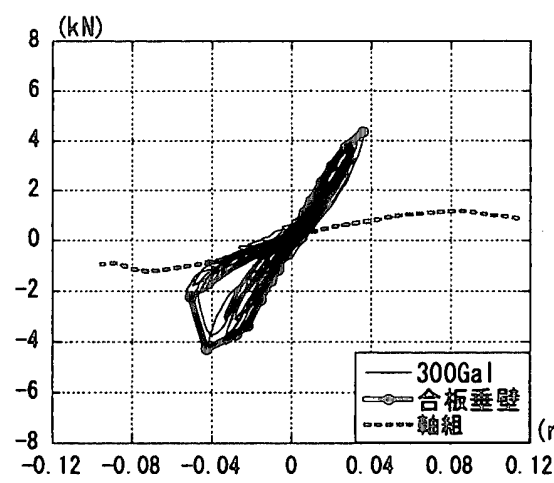

(d) 合板垂壁試験体

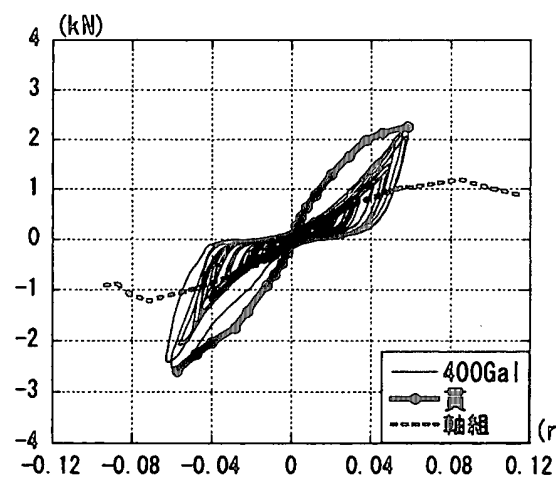

（g）貿䚾耠体

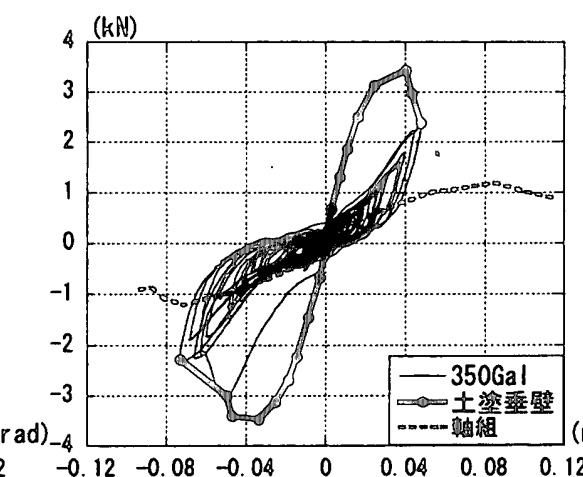

(b) 土塗垂壁試倹体

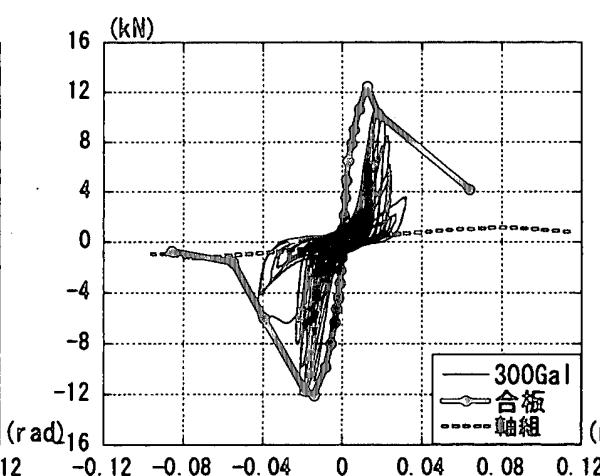

(e) 合板試験体

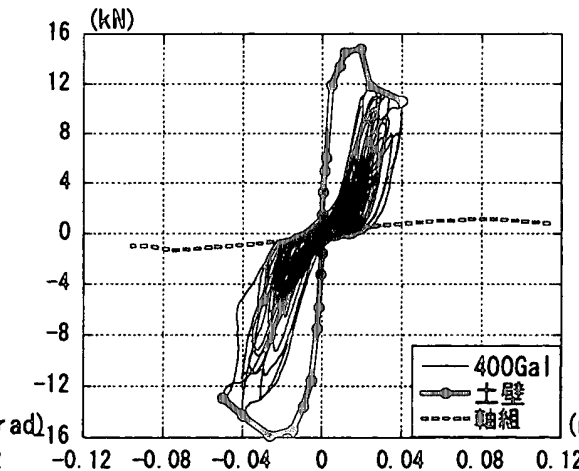

(h) 土壁試匼体

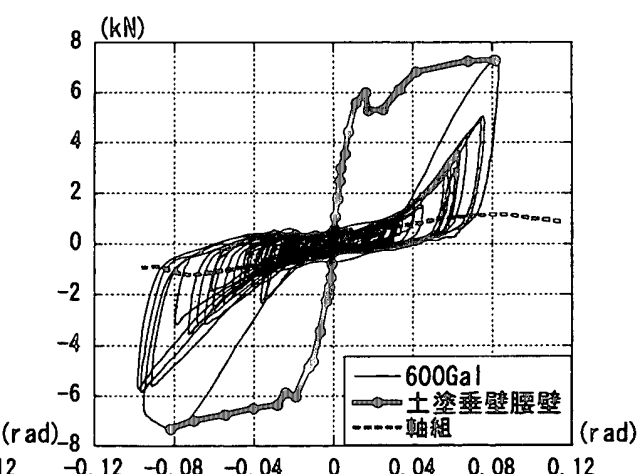

(c) 土潐垂壁腰壁試験体

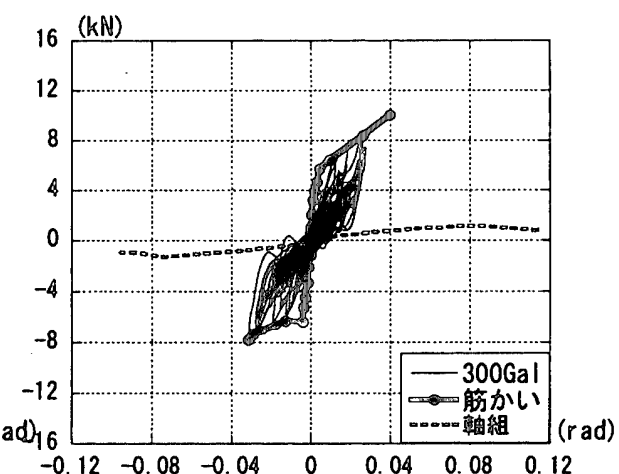

(f) 筋加小試験体

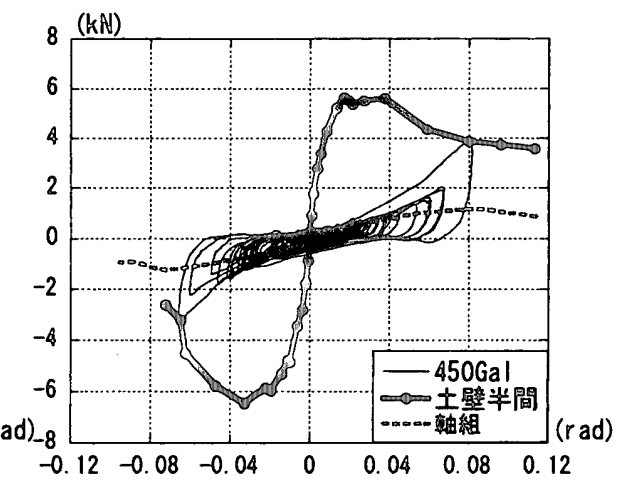

(i) 土壁半間試験体

図 4 各試験体の復元力特性

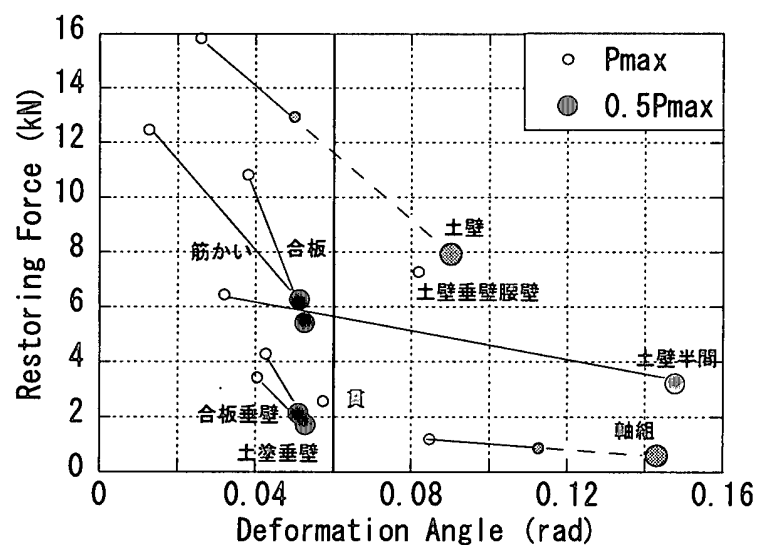

図 5 最大耐力之耐力半減時の変形性能

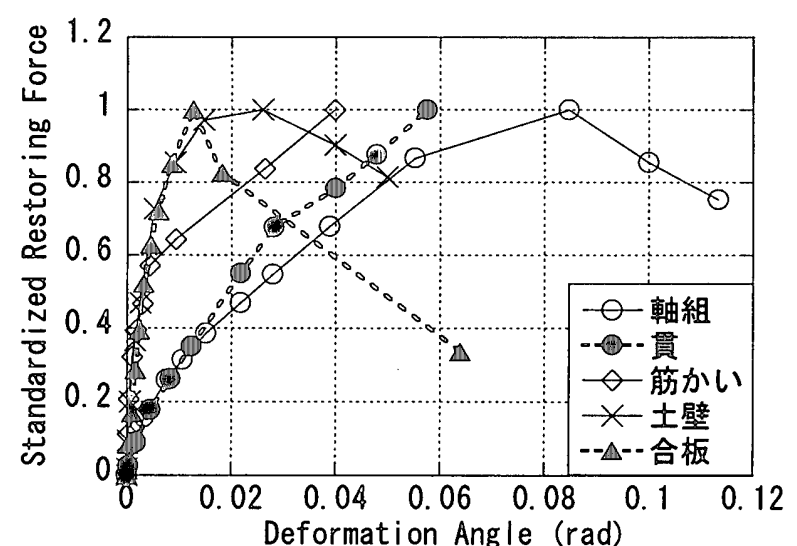

図 6 復元力特性（最大耐力で基準化） 
絡線上の変形角までしか考慮されておらず、大変形時に至るまで耐 力が低下しないという性質はこの計算法では評価されない。壁倍率 は、軸組の耐震性能の簡便な指標であるが、木造建物には様々な構 法があり、すべての構法を一様に評価することは難しい。それぞれ の構法の特徵に応じて、最大耐力後の耐力低下を考慮し得るような 耐力とともに変形性能を加味した適切な耐震性能評価を行う必要が ある。

\section{4. 動的実験結果と静的実験結果の比較}

動的実験では、試験体の破罗状況や実験施設の限界により、大变形時 まで実験できない場合も多い。そこで、現在多く行われている静的実験 と動的実験の結果を、復宇力特性と減衰性能の観点から比較し、静的実 験で把握できる試験体の耐震性能の妥当性を検証する。

\section{1 復元力特性の比較}

図 7 は代表的な 4 つの試験体の復元力特性である。太実線は動的 実験における復元力特性の包絡曲線を示し、細実線は静的実験にお ける復元力特性を示す。

動的実験と静的実験を比較すると、両者の包絡曲線は比較的よく 一致している。特に初期剛性は図上においてほとんど差がない。し かし、層間変形角が 0.02rad を超えると、軸組試験体では、動的実 験の復元力が静的実験の復元力よりも大きくなる。また、土壁試験 体では、正側と負側で異なるが平均的には、動的実験の復元力が静 的実験の復元力よりも大きくなる。載荷速度の違いが復元力特性に 影響していると思われる。一方、脆性的な破壊の生じた筋かい試験 体と合板試験体では、静的実験よりも動的実験の方が先に破壊が生 じる場合があり、復元力特性も静的実験の結果が動的実験を上回っ ている。これらの試験体では、静的実験よりも動的実験の方が繰り 返し載荷の効果を強く受けて、筋かい端部の釘や合板の留め付け釘 が抜けたり、破損することや、材のバラツキが脆性的な破壊に大き く影響することなどが関倸していると考えられる。

\section{2 履歴消費エネルギーの比較}

各試験体のエネルギー消費能力を調べるために、復元力特性の履 歷面積を算出した。図 8 は動的実験と静的実験の履歴面積を比較し たものである。動的実験では、繰り返して加振を行っているために、 最大変形角を更新しないループではスリップ特性が顕著に現れ、㑉 性とともに履歷面積が小さくなってしまうため、各加振において履 歴面積が最大となる半ループを取り出して面積を求めた。静的実験 では、正負交番載荷を行っているので、履歴曲線が y 軸を横切るた びにループを区切り、半ループの面積を算出した。図 8 の横軸には 各ループの最大変形角を取り、縌軸には履歴面積をとった。なお、合 板試験体では、同じ最大変形角で 3 回の繰り返し載荷を行っている ので、全てのループに対して履歴面積を算出した。

各試験体とも、小変形時には履歷面積は非常に小さく、変形が大きく なると共に履歴面積が線形的に大きくなる。損傷が発生すると履歷面積 の增加率が小さくなり、大変形時には変形角に関わらずほほ一定の履歷 面積となっている。

動的実験と静的実験の履歷面積を比較すると、合板試験体を除く 試験体で、変形角が 1/50 rad 以下では両者の結果は比較的よく一致 し、変形角が大きくなると、動的実験の履歴面積の方が静的実験の
表 2 試験体の壁倍率

\begin{tabular}{|c|c|c|c|c|c|c|c|}
\hline \multirow[b]{2}{*}{ 試験体名 } & \multicolumn{4}{|c|}{ 動的実験より算出した耐力 $(\mathrm{kN})$} & \multicolumn{3}{|c|}{ 壁倍率 } \\
\hline & $P_{y}$ & $P_{150}$ & $\frac{2}{3} P_{\max }$ & $0.2 \frac{P_{u}}{D_{s}}$ & 動的結 & 静的結果 & 現行 \\
\hline 短ほぞ105角 & 0.6 & 0.3 & 0.8 & 0.4 & 0.1 & 0 & 0 \\
\hline 土塗垂壁 & 2.0 & 1.2 & 2.3 & 1.4 & 0.3 & 0.3 & 0 \\
\hline 土塗垂壁腰壁 & 5.2 & 3.5 & 4.9 & 3.8 & 1.0 & 0.9 & 0 \\
\hline 合板垂壁 & 3.2 & 1.1 & 2.9 & 1.3 & 0.3 & 0.3 & 0 \\
\hline 合板 & 6.4 & 8.7 & 8.0 & 5.7 & 1.6 & 1.0 & 2.5 \\
\hline 筋かい & 5.5 & 6.1 & 6.7 & 5.7 & 1.5 & 1.1. & 2.0 \\
\hline 貫 & 1.1 & 0.6 & 1.5 & 0.7 & 0.2 & 0.2 & 0 \\
\hline 土壁 & 9.8 & 12.3 & 10.6 & 11.6 & 2.7 & 2.1 & 0.5 \\
\hline 土壁半間 & 2.9 & 3.7 & 3.8 & 3.8 & 1.6 & 0.6 & 0.5 \\
\hline
\end{tabular}

※ 表中において太字は壁倍率を算出する基準となった耐力を示す。

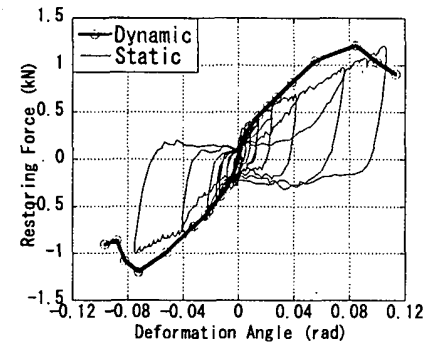

(a) 軸組試験体

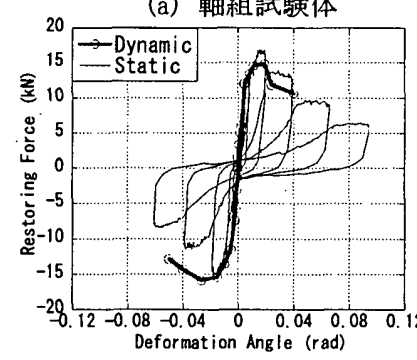

（c）土壁試験体

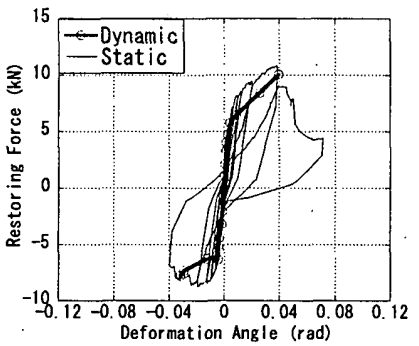

（b）筋加試験体

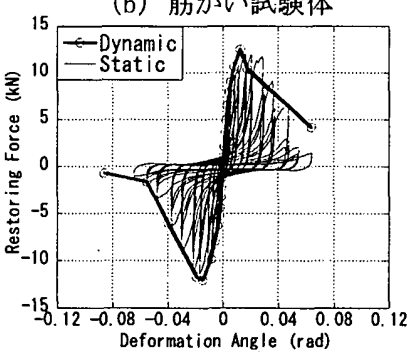

(d) 合板試験体
図 7 復元力特性の包絡曲線の比較

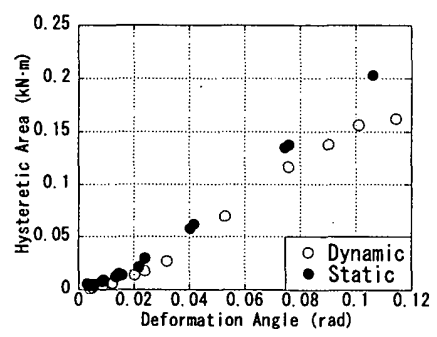

(a) 軸組試験体

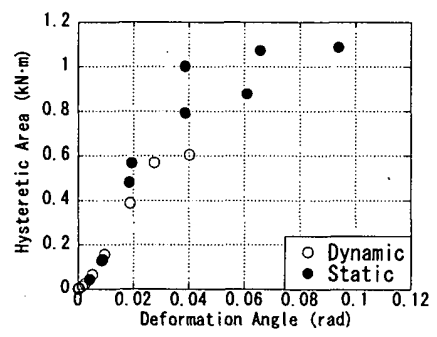

(c) 土壁試験体

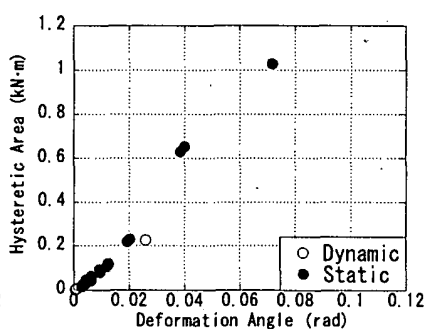

(b) 筋加以試験体

(d) 合板試験体

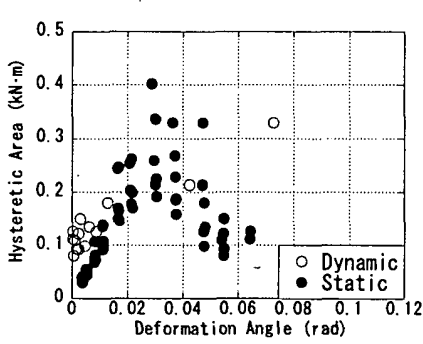

図 8 履歷面積の比較 
結果よりも小さくなっている。この傾向は特に軸組試験体に顕著に 現れ、その差は 2 割程度である。この理由は、以下のように考えら れる。軸組試験体の復元力特性は、柱頭、柱脚部のほぞによる仕口 に大きく依存しており、繰り返して行った動的実験では、ほぞ部分 のめり込みによるスリップ特性が顕著となり、動的実験から得られ た履歷面積は、繰り返し回数が少なく、最大変形を更新しながら行 う静的実験から得られる履歴面積より小さくなったためである。

筋かい試験体と土壁試験体では、動的実験において $1 / 25 \mathrm{rad}$ 以上 の変形時でのデータが得られていないが、小変形時の履歴面積は概 ね一致している。

土壁試験体の静的実験では、正負交番载荷で先に载荷される正側 は負側よりも損傷が少ないために履歷面積が大きく、後に载荷され る負側の履歷面積は小さくなるので、履歷面積は正側、負側の变形 角に対して変動しているが、1/10 rad近くで壁土が剥落するまでの 大きな変形まで大きな履歴面積を保持し続けている。

合板試験体で、復元力特性の低下とともに履歷面積も急激に低下 する。大変形時に動的実験の履歴面積が静的実験よりも大きくなっ たのは、動的実験において衝愘的な破壊が発生し、変形角が急激に 増加して履歷曲線が大きく膨らんだためである。静的実験において バラツキが大きいのは、同じ最大変形角で 3 回繰り返し载荷を行っ ているため、1 回目の载荷より 2 回目と 3 回目の载荷ではスリップ特 性が現れ、履歷面積が小さくなるためと考えられる。

\section{5.まとめ}

本研究では、軸組構法の木造建物の耐震性能評価法を確立するた めに、単位木造軸組に各種の耐震要素を組み込んだ試験体を用いて、 動的実験と静的実験を行い、破壊状況とともに復元力特性など動的 および静的耐霞性能の違いを調べた。本研究で得られた成果を以下 に列挙する。

静的実験に加えて動的実験を行うことにより、地震時に想定され る大変形時の破壊状況を確認することができた。脆性的な破壊の生 じた合板、筋かいなどの試験体は、合板の剥離や筋かいの折損によ り最大耐力後、急激に耐力が低下した。また、土壁や合板の垂壁付 きの試験体では、柱の曲げ破壞が生じて同様に急激な耐力低下を起 こした。垂壁部分のせん断耐力との兼站合いから柱の曲げ破壊を生 じないようにするならば、垂壁付き軸組は耐震要素となり得る。軸 組のみや貫試験体は、耐力は低いが、変形性能は高い。一間幅およ び半間幅の土壁試験体など破壊が徐々に進行する試験体は、最大耐 力後も変形が進んでも耐力が急激に低下せず、変形性能が高いこと が分かった。特に、土壁の垂壁・腰壁付き試験体は、1/10radの大 きな変形角まで耐力低下を起こさないことが分かった。

動的実験結果と静的実験結果から、復元力特性の包絡曲線につい て比較した。初期剛性にはほとんど差が見られなかった。また、変 形が大きくなっても概して大きな違いは見られなかったが、層間変 形角が 0.02rad を超えると、軸組試験体や土壁試験体では、動的実 験の復元力が静的実験の復元力よりも大きくなる傾向が見られた。 一方、脆性的な破壊の生じた竻かい試験体と合板試験体では、静的 実験よりも動的実験の方が繰り返し効果の影響を強く受けるため、 先に破壊が生じて復元力特性も静的実験の結果よりも動的実験の結
果が低くなっている。

履歷面積の比較では、脆性的な破壊の生じた合板試験体を除くす べての試験体で動的実験の履歷面積の方が静的実験の結果よりも小 さくなっている。動的実験の履歷特性が繰り返し加振によりスリッ プ特性が強く現れたためと考えられる。本研究で実験を行った耐震 要素を含めて木造住宅で用いられる耐震要素の多くが顕著なスリッ プ特性を有しているため、地震時のような繰り返しによって履歴を 経験した後の履歴面積は大きく堿少するので、エネルギー消費能力 については復元力特性と併せて詳細な検討が必要となる。

本研究では、種々の耐震要素を組み込んだ木造軸組の動的・静的 実験から耐震性能の違いなどに注目してまとめたが、今後、土壁全 面壁や土壁小壁などの水平力に対する抵抗メカニズムを検討し、よ り詳細に耐震性能について検証する。

\section{謝辞}

本研究の一部は、科学研究費補助金 (基盤研究 (A) (1)、課題番号 : 13305036、研究代表者 : 鈴木祥之) の助成を受け、平成 13 年度から 14 年度にわたって実施した。試験体の製作にはアラキ工務店・荒木正亘氏、 丸浩工業・村上博氏、大西工務店・大西隆氏、坂田工務店・坂田徳一氏 にご協力を頂いた。また、実験の実施において、京都大学防災研究所市 川信夫技官、京都大学防災研究所鈴木研究室および金沢工業大学後藤研 究室の学生諸君にご協力を頂いた。ここに記して感謝の意を表する。

\section{迢然文献}

1）坂本功、大㛢好光、田中裕樹、宮䐾健二ら：軸組構法住宅の実大振動実験 (A 棟) - ( F 棟)、日本建築学会大会学術講演梗概集、Vol. C-1、pp. 129156、1996. 9 .

2）鈴木祥之、中治弘行 : 木造住宅士叙り壁の実大実験による耐震性能の再検 討、日本建築学会構造系論文集、No. 515、pp. 115-122、1999.1.

3）鈴木样之、後藤正美、山田真澄 : 単位木造フレームを用いた振動台実験に よる木造軸組の耐震性能評価、第11回日本地震工学シンポジウム論文集、 pp. 1511-1516、2002.11

4）後藤正美、山田真澄、鈴木祥之: 木造軸組の動的・静的実験による耐震性 能評価、第 11 回日本地震工学シンポジウム論文集、pp.1517-1522、 2002.11.

5）中治弘行：木造建物の耐霞性能評価に関する研究、京都大学学位論文、 pp. 49-57、1999. 4 .

6）北原昭男、林康裕、奥田辰雄、鈴木祥之、後藤正美：2000年鳥取県西部地 震における木造建物の糔造特性と被害、日本建築学会構造系論文集、No 561、pp. 161-167、2002.11.

7) 日本建築学会木構造と木造文化の再構築特別研究委員会, 日本建築学会近 畿支部：「木構造と木造文化の再構築小、pp. 126-151、2001.3.

8）藤田香織、坂本功、大橋好光、木村正彦: 伝統的木造建築の壁体に関する 振動台実験 (その2) 土壁の地祳波加震、日本建築学会大会学衍請演梗概集、 Vol. C-1、pp. 149-150、1997.9.

9）木村正彦、藤田香織、大橋好光、坂本功：伝統的木造建築の壁体に関する 振動台夷戨（その3）板壁・通し貫の地震波加霞のまとめ、日本建築学会大 会学淮辆演梗概集、Vol.C-1、pp. 151-152、1997.9.

(2003年 5 月 8 日原稿受理，2004年 5 月 13 日採用決定） 